\title{
PERCEPTION OF INNOVATION AND ITS CHARACTERISTICS: THE CASE OF IZMIR
}

\author{
Lect. PhD. Murat NAZLI \\ Yasar University, Faculty of Business, İzmir, Turkey, (nazli.murat@gmail.com) \\ Asst. Prof. Evla MUTLU \\ Antalya Bilim University, College of Tourism, Antalya, Turkey, (eevlamutlu@gmail.com)
}

\begin{abstract}
Innovation literature includes studies observing the differentiation in perceptions related to stakeholders, industries, products/services etc. Despite, no similar studies are carried in Izmir, therefore the purpose of research is to understand and analyze the perception and concept of innovation in Izmir, Turkey. Sample size consists of 94 residents, where snowball sampling method is used. According to results $14 \%$ of the respondents stated that environment for innovation is not very satisfactory while $66 \%$ of the respondents believed that there are promising developments. The study presents various perspectives of innovation for both practitioners and researchers.
\end{abstract}

Keywords: Innovation Perception, Innovative Firms and Sectors, Izmir, Turkey.

\section{INOVASYON VE KARAKTERISTIKLERININ ALGILANMASI: IZMIR ÖRNEĞİ}

\begin{abstract}
ÖZET
İnovasyonun literatüründe, paydaşlar, endüstriler, ürün ve hizmet gibi unsurlarla ilişkili olarak algıdaki farklılıkları inceleyen çalışmalar bulunmaktadır. Buna ră̆men, İzmir'de buna benzer bir çalışma yapılmamıştır, bu sebeple araştırmanın amacı, inovasyon kavramının İzmir'deki algısını anlamak ve analiz etmektir. Örneklem büyüklü̈̆̈̈ İmir'de yaşayan 94 kişidir ve kartopu örneklem yöntemi kullanılmıştır. Sonuçlara göre katılımcıların yüzde 14'ü, inovasyonun bölgede tatmin edici düzeyde olmadı ̆̆na inanmaktadı, yüzde 66's ise İzmir'de umut veren gelişmeler olduğuna inanmaktadır. Çalışma hem uygulayıcılar hem de araştırmacılar için farklı bakış açıları sunmaktadır.
\end{abstract}

Anahtar Kelimeler: Ínovasyon Algısı, İnovatif Firmalar ve Sektörler, İzmir, Türkiye. 


\section{Introduction}

Innovation according to Oslo Manual is the implementation of a new or significantly developed product (good or service) or process, a new marketing method or a new organizational method in business practices, workplace organization or external relations (OECD-Eurostat 2005: 46). Though this definition is widely recognized, several explanations of innovation are carried as Yanchenko (2013) summarizes the concept of innovation as; a process, a system, a result, a tool, a new object or the transformation of existing state. Due to the complexity in definition, various indices are developed and the specifications of these indices are observed to expose the main differences in inputs and outputs.

Besides the variety of definitions, the perception of innovation is another subject to study. Perception studies are generally about the customers perception of a specific innovative product/service (Onişor \& Roşca, 2013; Charles \& Issifu, 2015; Okereke, 2015), the perception of a specific innovative property of a product/service (Besier, 2015), perception of a specific type of innovation (Dabrowska et al., 2013), perception of innovation in a specific sector/group (Karaca, 2009; Pop et al., 2012; Anamaria \& Maria-Cristina, 2013; Iorgulescu \& Răvar, 2013; Abadi, 2014; Roussy et al., 2014; Gorghiu et al., 2015), forecasting the perception of customers (Lowe \& Alpert, 2015). Hence, the perception of innovation is a current issue despite being a long-established term.

Correspondingly, this study specifically aims to discover the innovation perception of university students, professionals in a foundation university and these professionals' connections in Izmir, Turkey. Moreover, not only the concept of innovation, but also the perceived innovative sectors, Izmir's perceived status in innovative studies are also the research areas of this study.

In the first part of this research, the theoretical background about the concept of innovation and innovation in organizations will be studied. Secondly, the methodology, findings and the evaluation of the findings will be addressed clearly. In the last part of the study, the conclusion and implications of the research depending on the responses, limitations and the future research recommendations will be provided.

\section{Perception of Innovation}

In this chaotic and developing world, innovation is occupying a significant role for the economic development and the survival of the organizations. In order to differentiate from the competitors or to increase their market share, innovative firms search for new technologies, products or services etc. Through this process, definition of innovation can be challenging, questioning the novelty, sustainability, customer-friendliness, ecological properties or quality of innovative issues.

Although since the late 1880 s, there have been reports of the use of the term "innovation" to mean something unusual, none of first precursors of innovation have been as influential as Joseph Schumpeter (Sledzik, 2013). From a Schumpeterian point, indicators concerning the framework conditions of development will have an influence on the index quality (Hanush $\&$ Pyka, 2007). Due to this influence of indicators, the methods used in the measurement of 
innovation have been altered in the course of time. When this period of time is researched, the approach to the measurement of innovation can be separated into four stages (Stone et al., 2008):

- In the first stage, between 1950 and 60s, the main emphasis was on inputs in innovation measurement. These inputs were research and development, capital and intensity of technology.

- In the second stage, between 1970 and 80s, due to science and technology activities, the emphasis was on main outputs such as patent, publications, products and transformation of quality.

- In 1990s, focal point was on the results of survey research. This stage includes the comparison of innovation capacities, indices and surveys.

- In 2000s, the last stage, process indicators come into prominence which are information, intangible resources, network structure, demand, management techniques, return of risk and system dynamics.

There are several studies about the perception of innovation. For instance, Gleim et al. (2015: 17) focus on the innovation perceptions of customers who are the ultimate decision makers about the innovation's success or failure. In this study, perceived innovation directly affects the perceived quality and anticipated satisfaction, and supported by the data gathered from 342 respondents. The model is shown in Figure 1, as seen perceived quality is defined as a mediator;

\section{Figure 1: Innovation Perception of Customers}

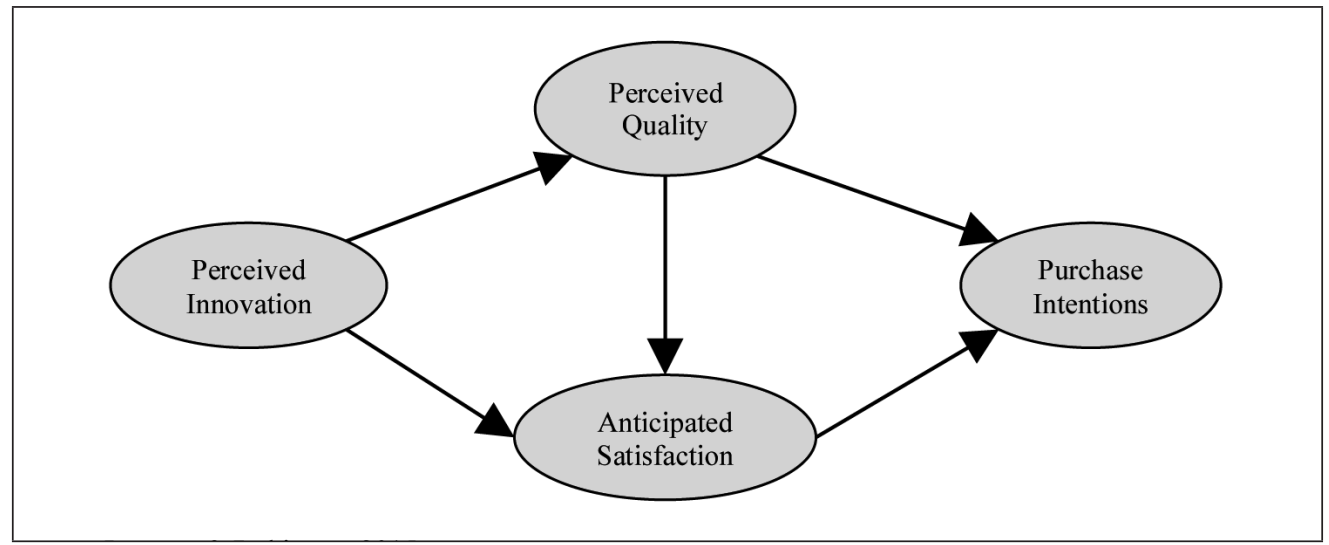

Source: Gleim, Lawson \& Robinson, 2015.

Schreier et al. (2012) also search for the perceptions of customers about innovative products designed by the users, and define the subjects in building positive perceptions. Another study is carried about the perception of open innovation, which is a relatively new approach (Dabrowsk et al., 2013). Accordingly, Dabrowska and his colleagues observe three case firms 
claims to execute open innovation in three levels; perceived openness, actual openness and targeted openness. Results show the different perceptions of the case firms although the actual openness are evaluated to be similar. Abadi (2014) underlines the dynamicity of the meaning of innovation in studies on construction industry.

\section{Innovation in Organizations}

As Amabile (1988) indicates; in business, in the 1980s, it was impossible to get away from innovation and it was impossible to read newspaper or business journals, attend business conferences or read annual reports without constantly hearing about the significance of innovation. Accordingly, the author underlines the demand of constant and visionary innovation related to domestic and international competition, changing government regulations, fast altering market conditions.

In both academic and practitioner communities, it is commonly perceived that organizations should innovate to be effective and to survive, and research can guide the management of innovation in organizations (Damanpour \& Schneider, 2006; Tidd, 2001; Drazin \& Schoonhoven, 1996). These scholars have researched questions of interest to top managers, such as what organizational processes facilitate the generation or adoption of innovation and why some organizations are able to adopt or generate more innovations than others. Despite many studies, these questions are not clearly responded and more research is recommended to identify the characteristics, factors or indicators of innovative organizations according to the authors.

According to Dasgupta and Gupta, in today's tough business environment, all organizations are concerned with demands for change. In addition, globalization and market segmentation have reinforced in organizations the need to differentiate, exploit advantages derived from selective integration of core competencies, and leverage intangible assets. It calls for an organization that encourages experimentation, learns about new applications and technologies, monitors the environment, evaluates its performance, and is committed to improving its performance. The organizational strategies, reward system, structure and communication practices must be redesigned so as to encourage innovation and change. In fact, organizations that string together a series of temporary and adequate advantages will outperform organizations that stick with one advantage for a long period of time (Dasgupta \& Gupta, 2009).

As Peter Drucker mentioned "The corporation as we know it is unlikely to survive the next 25 years. Legally and financially, yes. But not economically and structurally." (Daly, 2000). Firms are slowly embracing the power of openness and innovation - not just products or services, but also processes and various types of business models. This is a new way of being for businesses, to pursue opportunities while managing risks that come along with globalization (Shuman \& Twombly, 2010).

\section{Innovation in Izmir, Turkey}

Izmir, as stated by Izmir Development Agency (2016), is a major city of Turkey with its rich natural resources, having a significant potential for investors with its strategic location, 
logistics infrastructure, qualified human capital, investment areas with special incentives, multisectoral economic structure and high living standards. Innovation in Izmir is a niche topic, though studied by some researchers (Y1lmaz, 2010; Temel et al., 2011; 2013; Kesken et al., 2014) and by some institutions such as Izmir Development Agency, perception of innovation is not studied.

Related to the institutional studies, Izmir Development Agency funded a 7 million Turkish liras project aimed to create a centre of innovation in Izmir (IZTEKGEB İnovasyon Merkezi, n.d.) where 80 entrepreneurs will facilitate. Izmir Young Businessman Association (2015) is also actively involved in the innovation ecosystem, with the award of most innovative products, most innovative ideas and most innovative firms of Izmir.

Funded by Izmir Development Agency, a recent study conducted by Yasar University in Izmir investigated the innovative approaches of organizations which make their innovative perspectives as their core purpose, along with the method of case study (Karaata et al., 2016). According to the results, one of the firms stated that "We will continue our work by adding value to Izmir with our creative and innovative projects and this is our primary purpose." In general, 20 researched innovative firms in Izmir believed that creating something new which has not existed before drives their motive and inspires their innovative activities. In addition, the firms, with these innovations, help the ecosystem with the purpose of social responsibility.

Izmir also includes nine universities, where one of these universities, Izmir Higher Technology Institute, is in the top 10 of the Entrepreneur and Innovative University Index 2015 rankings organized by The Scientific and Technological Research Council of Turkey (2015). Besides, remaining three universities are also in the top 50 rankings; Ege University is 15th, Dokuz Eylul University 23th, University of Economics is the 39th. This scene underlines the growing potential of universities as technology transfer facilitators and fostering potential of innovation.

\section{Methodology}

The main purpose of the research is to study the concept of innovation, understand and analyze the degree of perception of innovation by the students, staff and their possible connections related with the topic, specifically in a foundation university in Izmir and by this way, to observe various point of views about the concept. In order to measure the perception of innovation, a survey is prepared to understand innovation from different perspectives, to comprehend tendencies of the respondents in describing the concept of innovation. Data were gathered from the respondents in a foundation university by the use of snowball sampling technique. Basically, a total of nine questions, four of them demographic (age, gender, educational background, industry the participants work in), were asked to the respondents. The questions excluding the demographic factors are as follows:

1. How do you define the concept of innovation?

2. Which factors can be essential in making innovation real in a firm?

3. Are firms enough to present innovative goods and services in Turkey? 
4. In which areas innovation exists in Turkey?

5. How do you see the innovative activities of the firms in Izmir?

The prepared questions are open ended and the respondents are not limited for a quota of word count. The questionnaires are conducted via google drive's tools. Questionnaires are sent via social media and 94 participants responded the questionnaire in eight weeks.

Furthermore, raw data is obtained as excel format and all the respondents answered the questionnaire properly. Demographic characteristics are analyzed as descriptive analysis and open ended questions are evaluated with the content analysis.

\section{Findings}

A total of 94 participants took place in the research. Fifty percent of the respondents is female. Mean age of the male respondents is 34 and mean age of the female respondents is 31 . In their educational backgrounds, 41.4 percent of the respondents has an undergraduate degree, 27.6 percent master's degree, 18 percent high school degree, 11.7 percent doctorate degree and one of them has an associate degree. In addition, 21 respondents were regular undergraduate students and 28.8 percent of the respondents are employed in the university. Moreover, 15.1 percent of the respondents work in the tourism and hospitality industry, 10.9 percent in information technology, 9.6 percent in food and agriculture, 8.2 percent each in medical health services and construction/real estate, 5.5 percent in banking and 2.7 percent each in energy and automotive/subsidiary industry who have several degrees.

Table 1: Selected Sample Characteristics

\begin{tabular}{llcc}
\hline Criteria & & Number & Percent \\
\hline Gender & Male & 47 & 50 \\
\hline & Female & 47 & 50 \\
\hline Education & Total & $\mathbf{9 4}$ & $\mathbf{1 0 0}$ \\
\hline & Undergraduate & 39 & 41.4 \\
\hline & Masters & 26 & 27.6 \\
\hline & High School & 17 & 18.0 \\
\hline & Doctorate & 11 & 11.7 \\
\hline Industry & Associate Degree & 1 & 1.06 \\
\hline & Total & $\mathbf{9 4}$ & $\mathbf{1 0 0}$ \\
\hline & Education & 21 & 28.8 \\
\hline & Tourism Industry & 11 & 15.1 \\
\hline & Information Technology & 8 & 10.9 \\
\hline & Food and Agriculture & 7 & 9.6 \\
\hline & Medical Health Services & 6 & 8.2 \\
\hline & Construction/Real Estate & 6 & 8.2 \\
\hline & Banking & 4 & 5.5 \\
\hline
\end{tabular}


Table 1 continue

\begin{tabular}{lcc}
\hline Logistics & 3 & 4.1 \\
\hline Energy & 2 & 2.7 \\
\hline Automotive/Subsidiary Industry & 2 & 2.7 \\
\hline Chemistry & 1 & 1.4 \\
\hline Textile & 1 & 1.4 \\
\hline $\begin{array}{l}\text { International Trade and } \\
\text { Investment }\end{array}$ & 1 & 1.4 \\
\hline Total & $\mathbf{7 3}$ & $\mathbf{1 0 0}$ \\
\hline
\end{tabular}

\subsection{Definition of Innovation as a Concept}

Table 2 basically reveals that innovation concept is mostly ( 29 percent) related to being new, novel and change. Within 29 percentage, meaning 27 respondents, 7 of them defined innovation only related to its being new.

Some respondents define innovation for both situations; indicating that it can be totally new or some improved form of an existing thing and 8 percent of the respondents stated that innovation is development, improvement and enhancement. The other eight percent stated that it is product based innovation and 7 percent each expressed that innovation is based on service and it is presenting something new to the market.

Table 2: Definition of Innovation Based on 94 Responses

\begin{tabular}{lcc}
\hline Expression & Frequency & Percent* \\
\hline Novel, new, changed & 76 & 29 \\
\hline Development, improvement, enhancement & 21 & 8 \\
\hline Product based innovation & 21 & 8 \\
\hline Service based innovation & 17 & 7 \\
\hline Offering something new & 17 & 7 \\
\hline Improving existing one & 16 & 6 \\
\hline Applying, producing, implementing & 16 & 6 \\
\hline Defined target & 13 & 5 \\
\hline Bringing added value & 9 & 3 \\
\hline Being sustainable & 9 & 3 \\
\hline Unusual, has not been done before & 7 & 3 \\
\hline Commercialization & 7 & 3 \\
\hline Facilitating technology & 6 & 2 \\
\hline Inclusion of research phase & 4 & 2 \\
\hline Having social dimension & 4 & 2 \\
\hline
\end{tabular}

* Expressions under 1 percent are not involved in the table; increasing competition, being limitless and endless, entrepreneurship, being solution oriented, defining actors who innovate, marketing innovation, increasing efficiency, reliability, organizational innovation. Percent is calculated according to total frequency of all expressions. 
For example, a 28 year male defined innovation as; "Innovation is beyond novelty and should be evaluated in terms of its successful trade, market share and number of people it influences. It is formed by four factors; human, trade, design and technology."

\subsection{Essential Factors of Innovation in a Firm}

Table 3 represents the critical factors of innovation in an organization expressed by 94 respondents. Some of the top expressions stated by the respondents are; human resources (9 percent), making research and being up to date (9 percent), organizational culture and point of view (9 percent), bringing novelty and being creative (9 percent), financial support (9 percent), and support of leaders or top managers ( 8 percent).

\section{Table 3: Factors of Innovation in a Firm}

\begin{tabular}{llc}
\hline Expression & Frequency & Percent* \\
\hline Human resources & 23 & 9 \\
\hline Making research, being up to date & 23 & 9 \\
\hline Organizational culture, point of view & 22 & 9 \\
\hline Bringing novelty, being creative & 22 & 9 \\
\hline Financial support & 21 & 9 \\
\hline Support of leaders or top managers & 20 & 8 \\
\hline Motivation, desire & 12 & 5 \\
\hline Existence of innovation in strategy and vision & 11 & 5 \\
\hline Knowledgeable about the subject, mastering technical process & 8 & 3 \\
\hline Proper facility and working conditions & 8 & 3 \\
\hline Producing, implementing, applying & 7 & 3 \\
\hline Being sustainable, providing continuity & 7 & 3 \\
\hline Awareness of the needs, related to the needs & 7 & 3 \\
\hline Following technology, adjusting today's technology & 6 & 2 \\
\hline Training employees & 5 & 2 \\
\hline Development, improvement & 4 & 2 \\
\hline Ability to compete, knowing the sector & 4 & 2 \\
\hline Strong communication, accessibility, openness & 4 & 2 \\
\hline * Expressions under 1 percent are; presenting different ideas which have not tried before, suitability of the \\
organizational structure, being future oriented, creating added value, being courageous, being dynamic, taking risk, \\
being an entrepreneur, flexibility, marketing and public relations, design, environmental factors, providing resource, \\
commercialization, increasing efficiency, happiness at work.
\end{tabular}

Additionally, some of the sample responses about the factors of innovation in a firm are expressed as follows; A 29 year old female stated that "To innovate in a firm, managers should have an open mind and entrepreneurial spirit. They should provide resources to research and development department and the employees should be eager to produce new products and make research." 
A 45 year old female stated that “The employees' openness to new ideas, following and interpreting new trends, having practical intelligence, after finding a solution to the problem, transferring what is learned to real life are all critical."

\subsection{Firms' Sufficiency to Present Innovative Goods and Services in Turkey}

Based on 94 respondents' views, 64 percent of the respondents claim that the firms are not sufficient enough to innovate, 27 percent of the respondents are temperate, claiming that some firms are developing and innovative goods or services will increase in time. Only 7 percent of the respondents believe that firms are sufficient in this manner and 2 percent do not have an idea. In some views, the areas that are good at in the matter of innovation are presented as; Firms which have research and development department, firms that do research projects funded by Turkish Scientific and Technical Research Institute, telecommunication sector, five star hotels in service sector, decoration and furniture sector, and work being done in engineering field.

Some sample quotes related with the adequacy of firms to present innovative goods and services in Turkey, are stressed as follows;

For instance, a 28 year old female mentioned that "To me, the concept of innovation is less understood in our country and lacks applications. To provide appropriate products for the consumers, trying to fully understand the needs of them is essential. To make innovation real, there has to be a perfect management of commercial periods gathered with correct design and technology."

A 29 year old female emphasized that "Research and development departments are not sufficient and the employees are canalized to routine jobs and assignments. The motivation should be much higher for innovative products.

\subsection{Areas That Innovation Exists}

Due to the responses of 94 respondents, the construction industry is mentioned 10 times, Tourism Industry, Technology and Health Industry 9 times each, Services Industry and Information Technologies 8 times each, by the respondents. In Table 4 , the expressions related with the existing areas of innovation in Turkey, are stressed clearly as follows:

Table 4: Areas of Innovation in Turkey Stressed by 94 Respondents

\begin{tabular}{lcc}
\hline Expression & Frequency & Percent \\
\hline Construction Industry & 10 & 10.6 \\
\hline Tourism Industry & 9 & 9.57 \\
\hline Technology & 9 & 9.57 \\
\hline Health Industry & 9 & 9.57 \\
\hline Services Industry & 8 & 8.51 \\
\hline Information Technologies & 8 & 8.51 \\
\hline
\end{tabular}


Table 4 continue

\begin{tabular}{|c|c|c|}
\hline Industry Sector & 7 & 7.44 \\
\hline Defense Industry & 7 & 7.44 \\
\hline Automotive & 7 & 7.44 \\
\hline Education & 6 & 6.38 \\
\hline Banking & 6 & 6.38 \\
\hline Textile & 5 & 5.31 \\
\hline Food Sector & 5 & 5.31 \\
\hline Electronics & 5 & 5.31 \\
\hline $\begin{array}{l}\text { Software; Home Appliance; Restaurant, Coffee; Furniture Industry } \\
\text { (home decoration); Communication (telecommunication firms, } \\
\text { web services, satellite systems); Engineering; Transportation (ship, } \\
\text { marine, bridge); Production; Machine Industry; No innovation; } \\
\text { Innovation can happen anywhere if there is openness to development }\end{array}$ & 3 & 3.19 \\
\hline $\begin{array}{l}\text { Entertainment; Marketing; Chemistry; Agriculture; Energy, Izmir, } \\
\text { Istanbul, Ankara, Antalya, Kocaeli, Bursa }\end{array}$ & 2 & 2.12 \\
\hline $\begin{array}{l}\text { Shopping centers; Packaging; Biomedicine; Fashion; Ceramic; } \\
\text { Advertising; Architecture; Municipal work; Private sector, large } \\
\text { scale firms; Industrial areas; Research and development; Cleaning } \\
\text { products; No idea }\end{array}$ & 1 & 1.06 \\
\hline
\end{tabular}

In addition, sample responses about the existence of innovation in Turkey are as underlined below;

A 29 year old female respondent stated that "Innovation exists in the areas of chemistry, software, biomedicine and renewable energy however, it is not sufficient and prototypes do not transform into final products."

A 21 year old male respondent mentioned that "For instance, in textile industry, a shirt is produced which hides air inside and it does not spread bad odor."

A 28 year old female emphasized that "There is entrepreneurial innovative activities in Turkey. Mainly, it is in electronics and information technologies. In general, it is done in electronics in SMEs or big scale firms. In information technologies, there is innovation mostly from startups.”

\subsection{Innovation Activities in Izmir}

Based on 94 respondents' point of views about the innovative firm activities, 20 percent of the respondents do not comment on innovative activities taking place in Izmir. However, 13.8 percent of the respondents stated that innovation focus is not enough and satisfactory in the region. The vast majority of the respondents, which is 66 percent, mentioned that there are significant developments and encouraging activities happening in Izmir. The detailed responses are emphasized in Table 5; 
Table 5: Innovative Activities of the Firms in Izmir Based on 94 Respondents

\begin{tabular}{|c|c|c|}
\hline Responses & Number & Percent \\
\hline Total response & 94 & 100 \\
\hline No idea & 19 & 20.2 \\
\hline Not satisfactory or enough & 13 & 13.8 \\
\hline Promising developments or encouraging activities & 62 & 66 \\
\hline \multicolumn{3}{|c|}{ Out of 62 respondents indicating promising developments or encouraging activities; } \\
\hline Universities & 8 & 13 \\
\hline Meetings, conferences, seminars, fairs, trainings & 7 & 11 \\
\hline Technology parks, incubation centers & 6 & 10 \\
\hline $\begin{array}{l}\text { Health sector (development of medicine, biomedicine, medical } \\
\text { products) }\end{array}$ & 6 & 10 \\
\hline Izmir Development Agency and other development projects & 4 & 6 \\
\hline Research and development centers & 4 & 6 \\
\hline Transportation (tramway, public transportation) & 4 & 6 \\
\hline $\begin{array}{l}\text { Service industry (innovative products in hotels and restaurants, } \\
\text { boutique hotels presenting different products/services) }\end{array}$ & 3 & 5 \\
\hline Furniture sector (innovative designs) & 3 & 5 \\
\hline Production and machine industry & 3 & 5 \\
\hline Food industry (presenting innovative products such as herb foods) & 2 & 3 \\
\hline Entertainment sector & 2 & 3 \\
\hline Infrastructure and energy & 1 & 2 \\
\hline Wind energy & 1 & 2 \\
\hline Shopping malls & 1 & 2 \\
\hline City planning (smart crossroads) & 1 & 2 \\
\hline Textile fairs & 1 & 2 \\
\hline Information technologies & 1 & 2 \\
\hline Construction sector & 1 & 2 \\
\hline Software & 1 & 2 \\
\hline Chemistry & 1 & 2 \\
\hline Privatization and increase in service quality & 1 & 2 \\
\hline
\end{tabular}

Furthermore, some opinions of the respondents about the innovative activities of the firms in Izmir are as follows; A 41 year old male respondent stated that "Bringing more qualified human capital to Izmir and adopting this capital with the industry through integration is essential." 
A 28 year old female mentioned that "There is an increasing effort related with innovation in recent years. Incubation centers, technology transfer offices are opened but supportive environment is not as big as that of other big cities. In the entrepreneurial ecosystem, a few entrepreneurs exist and their numbers are rising slowly. Small and medium sized enterprises lack flexibility. They are generally family-owned firms and have a traditional management approach.”

A 35 year old female respondent stated that "The number of meetings, conferences etc. about innovation is increasing. Additionally, I feel that a subsidiary sector which gives consultancy services is forming currently."

\section{Evaluation of Findings}

Various participants from different educational backgrounds and industries took place in this research. This type of variety brought a comprehensive understanding in defining the concept of innovation.

As seen in the findings, "being new" is recognized to be closely related to innovation. This perception is assumed to be the result of the dictionary meaning of the word, where "doing something new" and "making innovation" is used interchangeably in Turkish (Akalın, 2007).

Another topic to discuss is; despite referring product and service innovation, organizational and marketing innovation are low referred. Besides the distinction between "novelty" and "improvement" which is clearly stated by the respondents, some respondents define both of the issues as innovation.

Social expectations of innovation is another subject, which a respondent defines innovation as; "Not technical, a process based on society", and another respondent defines as; "A discovery which will increase efficiency and create added value to the industry and humanity". These comments emphasize the societal part of innovation.

The percent of expressions in factors of innovation in a firm is distributed respectively homogenous, unlike that of the definition of innovation. The definition of innovation includes 24 expressions in this research, though factors of innovation in a firm include 33 expressions based on the responses. In this situation, in perceiving this expression, it can be said that the conceptual variety is relatively high.

Highly mentioned expressions such as; human resources, making research and being update, existence of proper organizational culture, being creative and bringing novelty, financially supporting the ideas and support of top leaders or managers, indicates the essentially of these terms by the respondents. As seen in the results, respondents are generally interested in human-related issues, while the only expression that is not directly human-oriented is "Proper facility and working conditions".

A significant number of respondents do not think that the firms in Turkey are sufficient for innovation. These respondents cover 64 percent of all. Respondents who are temperate andless pessimistic, indicate the potential in the future of Turkey. Respondents who think that the firms are insufficient are 7 percent, which are considered to be minority for the sample of the study. 
According to 94 responses based on frequency of industries, the respondents believed that innovation takes place mainly in the Construction Industry, Tourism Industry, Technology and Health Industry, Services Industry and Information Technologies, in Turkey.

A male respondent brings a different perspective; "Even if innovative products and services are developed as ideas, most of them can not be actualized as a fact of insufficient capital" indicating that the financial issues are suppressing innovative goods and products. On the other hand, another female respondent; "Despite the long term investments in $R \& D$, innovative products are scarcely any", indicates that the financial support in R\&D is not the reason of the firm's insufficiency. This contradictve expressions reveal the perceptual diversion of respondents.

Due to respondents' views about the innovative activities of the firms, 20 percent of the respondents do not have an idea about the innovative activities and efforts taking place in Izmir. However, aptly 14 percent of the respondents underlined that innovation emphasis or work is not very satisfactory in the region but more than half of the respondents believed that there are significant developments and encouraging activities happening in Izmir. At this point, it is assumed that the innovation efforts of the region will increasingly continue in the near future.

\section{Conclusion and Recommendations}

This study is a result of researchers' inspiration about trying to understand the concept of innovation and it's characteristics through the perspectives of residents in Izmir. Accordingly, the study fundamentally investigated the perception level of innovation, essential characteristics influencing innovation, existence of innovation in Turkey and industries that innovation takes place, based on 94 respondents from various educational backgrounds, industrial experiences and expertise in Izmir, Turkey.

The study outcomes revealed that the understanding of innovation varies in individual level. Respondents use a human centric approach in common, while evaluating firms' essentials in innovation. A significant percent of respondents are also pessimistic about the innovative firms in Turkey. On the other hand, more than half of the respondents emphasized that there are substantial developments, heartening activities and efforts happening in Izmir. As stated by Karaata et al. (2016), twenty innovative firms in Izmir showed that creating something totally new which has not existed before drives their motive and inspires their innovative performances and activities. In addition, the firms, along with these innovations, help the ecosystem with the aim of social responsibility. In this perspective, it is assumed that the innovation endeavours of the region will progressively continue in the near future.

As Shuman \& Twombly (2010) underlined, the organizations are slowly embracing the power of openness and innovation - not only the products or services, but also the processes and several types of business models. This is the latest way of being for businesses, to go for business opportunities while managing the risks that come along with globalization. Along with this point of view, according to Dasgupta \& Gupta (2009), the organizational strategies and structure, reward system and communication practices should be redesigned in order to encourage change and innovation. 
Due to the research analysis, the findings and the exploratory study present a significant perspective to the business leaders, practitioners and decision makers in terms of understanding the characteristics of innovation and innovative efforts and shed a light for future scientific debates in this field of research.

\section{Limitations and Further Research}

The study comes with some limitations. First of all, it is an exploratory study intending to comprehend the perception level of innovation within only one foundation university in Izmir based on the responses of students, staff and staff connections that are reachable. Secondly, data collection period from the respondents was a hassle. Data were gathered within a limited time period along with a limited number of participants.

For future studies, a larger sample size with a quantitative analysis and point of view can strengthen the findings, results and implications and bring different point of views. Another proposal for future study is that a regional or industry specific empirical research can be done by considering the related indicators in the innovation or entrepreneurship indices in literature. In addition, the low referral of the marketing and organizational innovation in this research compared to the service and product innovation mentioned by the respondents, will lead to a future research and analysis about this field.

\section{References}

Abadi, A. (2014). A study of innovation perception within the construction industry (PhD Thesis). University of Manchester.

Akalın, Ş. A. (2007). Innovation, inovasyon: Yenileşim. Türk Dili Dil ve Edebiyat Dergisi, Türk Dil Kurumu Yayını, XCIII (666), 483-486.

Amabile, T. M. (1988). A model of creativity and innovation in organizations. Research in Organizational Behavior, 10 (1), 123-167.

Anamaria, R. \& Maria-Cristina, I. (2013). Consumer's perception on innovation in the tourism value chain, Annals of The University of Oradea. Economic Science Series, 22 (1), 815-824.

Besier, S. (2015). Generational perceptions of pro-environmental packaging advantages; A case study of the packaging innovation of 'compressed' deodorants in Germany. Uwf Umweltwirtschaftsforum, (4), 315. doi:10.1007/s00550-015-0375-2.

Charles, B. \& Issifu, Y. (2015). Innovation in education: Students' perceptions of implementing ICT in learning in second-cycle institutions in Ghana. Procedia - Social and Behavioral Sciences, 7th World Conference on Educational Sciences, 1512-1519. doi:10.1016/j. sbspro.2015.07.103.

Dabrowska, J., Fiegenbaum, I., \& Kutvonen, A. (2013). Mapping the perception and reality of open innovation. International Journal of Innovation Management, 17 (6), 1-25.

Daly, J. (2000). Sage advice: An exclusive interview with Peter Drucker. Retrieved July 8, 2017, from http://www .ghandchi.com/iranscope/Anthology/Drucker-SageAdvice.htm 
Damanpour, F. \& Schneider, M. (2006). Phases of the adoption of innovation in organizations: Effects of environment, organization and top Managers. British Journal of Management, 17 (3), 215-236.

Dasgupta, M. \& Gupta, R. K. (2009). Innovation in organizations a review of the role of organizational learning and knowledge management. Global Business Review, 10 (2), 203-224.

Drazin, R. \& Schoonhoven, B. C. (1996). Community, population, and organization effects on innovation: A multilevel perspective. Academy of Management Journal, 39, 1065-1083.

Gleim, M. R., Lawson, S. J., \& Robinson, S. G. (2015). When perception isn't reality: an examination of consumer perceptions of innovation. Marketing Management Journal, 25 (1), 16-26.

Gorghiu, G., Anghel, G. A., \& Ion, R. (2015). Students' perception related to a responsible research and innovation demarche. Procedia - Social and Behavioral Sciences, The 6th International Conference Edu World 2014: Education Facing Contemporary World Issues, November 7 - 9, 2014, 600-605. doi:10.1016/j.sbspro.2015.02.166.

Hanush H., \& Pyka A. (2007). Applying a comprehensive neo-schumpeterian approach to Europe and its Lisbon agenda. In 50 Years of EU Economic Dynamics (pp. 275-299). Springer Berlin Heidelberg.

Iorgulescu, M., \& Răvar, A. S. (2013). Measuring managers' perception of innovation in the Romanian hospitality industry. Procedia economics and finance, International Economic Conference of Sibiu 2013 Post Crisis Economy: Challenges and Opportunities - IECS, pp: 512-522, doi:10.1016/S2212-5671(13)00169-X.

Izmir Young Businessman Association (2015). İGİD inovasyon ödülleri, Retrieved April 13, 2016, from http://www.igid.org.tr/index.php

IZTEKGEB İnovasyon Merkezi (n.d.), İnovasyon Merkezi Hakkında, Retrieved April 13, 2016, from http://inovasyonmerkezi.blogspot.com.tr/p/hakknda.html

Kesken, J., Soyuer, H., Çağraz, B., İlic, D. K., Ünnü, N. A. A., Kocamaz, M., Çiçekli, U. G., Aracıoğlu, B., \& Koçak, A. (2014). Çalışanlar perspektifinden inovatif iş davranışının belirleyicileri: İzmir ilindeki öncelikli sektörlere ilişkin bir araştırma. Girişimcilik ve İnovasyon Yönetimi Dergisi, 3 (4), 25-48.

Karaata, S., Kesici, E., Hacıoglu, F., Dalgıc, G., Arbak, H., Nazlı, M., \& Taspınar, P. (2016). İzmir yenilik başarı hikayeleri. Izmir Development Agency, Retrieved March 1, 2016, from http://www.investinizmir.com/en/html/1128/Izmir+in+Numbers

Karaca, Y. (2013). Hizmetlerde inovasyon ve tüketici algısına etkisi: Yolcu taşımacılığ 1 sektöründe bir araştırma. Sosyal Bilimler Dergisi, 11(1), 195-212.

Lowe, B.\& Alpert,F.(2015). Forecasting consumer perception of innovativeness. Technovation, 45/461-14. doi:10.1016/j.technovation. 2015.02.001

OECD-Eurostat (2005). Oslo manual: Guidelines for collecting and interpreting innovation data, 3rd Edition. 
Okereke, E., Aminu, A., Butera, J., Mohammed, B., Tanko, M., Yisa, I., \& Tukur, J. (2015). An innovation for improving maternal, newborn and child health $(\mathrm{MNCH})$ service delivery in Jigawa state, northern Nigeria: A qualitative study of stakeholders' perceptions about clinical mentoring. BMC Health Services Research, 15(1), doi:10.1186/s12913-0150724-4.

Onişor, L. \& Roşca, M. (2013). Product innovation effect on consumer's perceptions. International Journal of Management Science \& Technology Information, (9), 17-26.

Pop, A. N., Săniuţă, A., \& Roman, M. (2012). Perception and communication of innovation in retail trade, Annals of the University of Oradea. Economic Science Series, 21 (1), 1200-1208.

Roussy, C., Ridier, A., \& Chaib, K. (2014). A methodological proposal to approach farmers' adoption behavior: Stated preferences and perceptions of the innovation. 2014 International Congress, August 26-29, 2014, Ljubljana, Slovenia.

Schreier, M., Fuchs, C., \& Dahl, D. W. (2012). The innovation effect of user design: exploring consumers' innovation perceptions of firms selling products designed by users. Journal of Marketing, 76 (5), 18-32.

Sledzik, K. (2013). Schumpeter's view on innovation and entrepreneurship. Retrieved March 26, 2015, from http://papers.ssrn.com/sol3/papers.cfm?abstract_id=225778

Stone, A., Rose, S., Lal, B., \& Shipp, S. (2008). Measuring innovation and intangibles: A business perspective. Washington: Institute For Defense Analyses - Science and Technology Institute.

The Scientific and Technological Research Council of Turkey (2015). TÜBITAK duyurular. Retrieved April 13, 2016, from http://www.tubitak.gov.tr/tr/kurumsal/politikalar/icerikgirisimci-ve-yenilikci-universite-endeksi

Shuman, J. \& Twombly, J. (2010). Collaborative networks are the organization: An innovation in organization design and management. Vikalpa, 35 (1), 1-13.

Temel, S. T., Akdeniz, R. T., \& Sukan, F. T. (2011). Ar-Ge ve inovasyon açısından İzmir KOBİlerinin durumu. Finans Politik ve Ekonomik Yorumlar, 48 (555), 83.

Temel, S. T., Akdeniz, R. T., \& Sukan, F. T. (2013). Bilgi tabanlı ekonomilere geçişte üniversitelerin ve üniversite-sanayi işbirliğinin yeri ve önemi: İzmir örneği. Finans, Politik ve Ekonomik Yorumlar Dergisi, 50 (578), 31-46.

Tidd,J.(2001). Innovation management in context: Environment, organization and performance. International Journal of Management Review, 3 (3), 169-183.

Yanchenko, Z. B. (2013). Improvement of terminological approaches to innovation notion definition. Problems of Economy, (2), 196-200.

Yılmaz, T. (2010). Küçük ve orta ölçekli imalat işletmelerinde yenilik (inovasyon) yönetimi: İzmir ili örneği (Yayımlanmamış Yüksek Lisans Tezi). Dokuz Eylül Üniversitesi, Sosyal Bilimler Enstitüsü. 